\title{
Terapi Kognitif Perilaku dan Kecemasan Menghadapi Prosedur Medis Pada Anak Penderita Leukemia
}

\section{Cognitive Behavior Therapy and Anxiety Facing Medical Procedures in Children with Leukemia}

\author{
Hinggar Ganari Mawandha* \\ Endang Ekowarni \\ Fakultas Psikologi Universitas Gadjah Mada, Yogyakarta 55281 \\ Diterima 2 April 2009 / Disetujui 20 Mei 2009
}

\begin{abstract}
Anxiety facing medical procedures always happenes in children with chronic disease. The aim of this research is to examine the effect of cognitive behavior therapy to reduce anxiety facing medical procedures in children with leukemia. Beginning from children's concept about their experince in hospital, cognitive behavior therapy has been used to reduce anxiety by changing cognition, emotion, and behavior. This research uses the single subject design with three participant, age seven to 11 years old. To measure anxiety, an adapted anxiety scale and the checklist of positive behavior had used. Cognitive behavior therapy administered individually, applied in five sessions. Quantitative analysis by visual inspection was conducted to show the anxiety score fluctuations. Qualitative analysis was done by analyzing the diaries, observation results, and interview results. The research show that cognitive behavior therapy can reduce the level of anxiety facing medical prosedures in children with leukemia.
\end{abstract}

Keywords: cognitive behavior therapy, anxiety, medical procedures, leukemia

Kanker menjadi salah satu penyakit ganas sepanjang sejarah, yang bersifat tersembunyi dan jahat, mudah menyebar serta merusak. Kanker diartikan sebagai kumpulan penyakit yang memiliki karakteristik pertumbuhan dan penyebaran sel abnormal yang tidak terkendali atau menyerang sel normal dan apabila tidak dapat dihentikan akan menyebabkan kematian (Sheridan \& Radmacher, 1992).

Kanker dapat menyerang segala usia, baik dewasa maupun anak-anak (Manne \& Andersen, 1991), misalnya kanker payudara lebih banyak ditemukan pada wanita dewasa, kanker paru-paru banyak ditemukan pada perokok akut, sedangkan kanker yang sering diderita oleh anak-anak salah satunya adalah leukemia (Siegel \& Hudson, 1992).

*Penulis Korespondensi :

Telp. (0274) 6714069, HP. 08122575505, Email : hinggarganari@yahoo.com 
Leukemia pertama kali diterangkan oleh seorang ahli faal bernama Bennet dari Skotlandia (Inggris Raya) dan seorang ahli patologi bernama Virchow di Jerman pada tahun 1845. Leukemia merupakan serangkaian gangguan yang ditunjukkan dengan sangat tingginya sel-sel darah putih yang tidak normal dalam sirkulasi darah (Gamayanti, 2006).

Leukemia disebabkan pertumbuhan sel yang tidak normal oleh sumsum tulang belakang. Ada dua klasifikasi leukemia yang didasarkan pada kecepatan kemajuan (progress). Pertama, leukemia akut, berkembang dengan sangat cepat dan menjadi penyebab kematian di tiap bulan. Jenis leukemia ini dapat menyerang di segala usia termasuk anak-anak (Ziegler, dkk., 2005). Kedua, leukemia kronis, kemajuannya sangat lambat dan cenderung diderita oleh orang dewasa (Sheridan \& Radmacher, 1992).

Intervensi yang dilakukan untuk pengobatan leukemia sebagai prosedur medis mencakup dua hal, yaitu terapi suportif dan spesifik. Terapi suportif meliputi transfusi yang bertujuan untuk mengatasi anemia dan mengontrol pendarahan (hemorrhage) serta pemberian antibiotik untuk mencegah terjadinya infeksi. Terapi spesifik meliputi kemoterapi dan radioterapi, yang memiliki efek jangka panjang (Nelson, dkk., 1969).

Masa pengobatan leukemia berlangsung 106-110 minggu dan tidak jarang mengalami efek samping seperti rasa mual, muntah, pusing, rambut rontok, diare, wajah menjadi sembab, bundar (moon face), dan terjadi komplikasi (infeksi, demam tinggi, pendarahan dan pneumonia). Pengobatan leukemia terdiri dari tiga fase: (a) Fase induksi remisi, yaitu diberikan dari minggu ke-0 hingga minggu ke-6; (b) Fase konsolidasi/intensifikasi, yaitu pengobatan diberikan dari minggu ke-6 hingga minggu ke-10; dan (c) Fase maintenance/pengobatan susunan syaraf pusat dan pengobatan lanjutan diberikan dari minggu ke-10 hingga minggu ke-106. Tujuan fase induksi adalah untuk mereduksi sel-sel leukemia secara cepat dan maksimal dan melakukan pencegahan terjadinya kondisi sakit lagi (relapse). Kegagalan dalam suatu fase akan menghambat pasien untuk masuk pada fase selanjutnya. Persiapan fisik dan mental pasien sangat penting untuk melanjutkan pengobatan pada fase berikutnya. Penelitian ini mengambil pasien pada tahap induksi remisi atau fase konsolidasi dengan alasan pasien belum terbiasa dengan pengobatan yang dijalaninya dan menimbulkan kecemasan yang tinggi. Beberapa penelitian menunjukkan bahwa anak-anak dengan penyakit kronis merasa tegang dan tidak nyaman dengan proses pengobatan dan efek samping yang ditimbulkan (Escudero, \& Craren, 2007), termasuk penyakitnya, suntikan dan perlakuan medis, serta respon emosional lainnya (Zempsky, dkk., 2007; Weinman, 1981).

Beberapa stresor ketika anak masuk rumah sakit adalah anak harus berpisah dengan anggota keluarganya saat menjalani prosedur medis, rasa sakit dan ketidaknyamanan pada 
penyakit, suntikan atau perlakuan medis, merasa asing dengan lingkungan rumah sakit, imobilitas, terganggunya rutinitas, menjadi tergantung kepada orang lain, kerusakan badan (perubahan fisik). Semua itu menimbulkan rasa malu, serta terjadi kesalahan dalam membentuk konsep tentang tujuan dari rawat inap (opname) di rumah sakit beserta prosedur medisnya (Siegel \& Hudson, 1992). Prosedur medis yang diterima anak-anak khususnya yang menderita penyakit kronis (leukemia) menimbulkan kecemasan dan depresi (Escudero, dkk., 2007). Beberapa anak yang menjalani rawat inap menunjukkan reaksi bermusuhan, mengalami kemunduran, menunjukkan perilaku ketergantungan seperti menarik diri, mengompol, merasakan ketakutan yang berlebihan, memberontak dan meronta-ronta (Taylor, 2006). Rasa sakit merupakan interaksi kompleks antara fisiologis, psikis, sosial dan perilaku (Taylor, 2006). Realisasi dari rasa sakit akan menghasilkan depresi, kecemasan dan kemarahan yang akan berpengaruh pada perilaku. Kecemasan merupakan salah satu kondisi psikologis yang biasa terjadi karena pengalaman tidak menyenangkan yang dialami oleh setiap manusia. Oleh karena itu, tidak mengherankan jika banyak ditemukan kasus kecemasan pada individu yang mengalami gangguan fisik, bahkan mencapai $50 \%$ pasien medis (Hersen, dkk., 1986). Kecemasan merupakan suatu keadaan khawatir, gugup, atau takut ketika berhadapan dengan pengalaman yang sulit dalam kehidupan seseorang dan menganggap bahwa sesuatu yang buruk akan terjadi (Greenberger \& Padesky, 1995; Nevid, dkk., 2005).

Simtom kecemasan sangat bervariasi dan berbeda untuk setiap individu. Simtom kecemasan dapat mengganggu kualitas hidup seseorang karena dapat mempengaruhi kemampuan seseorang untuk menjalankan berbagai aktivitas (Greenberger \& Padesky, 1995). Seseorang yang mengalami kecemasan akan mengalami simtom-simtom seperti: (1) Simtom fisik, meliputi gemetar, keluar banyak keringat, jantung berdetak kencang, sulit bernafas, pusing, tangan dingin, mual, panas dingin, lebih sensitif atau, kegelisahan, kegugupan, pingsan, merasa lemas, sering buang air kecil, dan diare; (2) Simtom perilaku, ditunjukkan dengan perilaku menghindar, perilaku ketergantungan atau melekat, perilaku terguncang, dan meninggalkan situasi yang menimbulkan kecemasan; dan (3) Simtom kognitif, yaitu khawatir tentang sesuatu, keyakinan bahwa sesuatu yang mengerikan akan segera terjadi tanpa ada penjelasan yang jelas, merasa terancam oleh orang atau peristiwa, kebingungan, dan khawatir akan ditinggal sendiri (Greenberger \& Padesky, 1995; Nevid, dkk., 2005).

Salah satu pendekatan terapi yang efektif untuk mengatasi kecemasan adalah Terapi Kognitif Perilaku (Cognitive Behavior Therapy) (Westra \& Phoenix, 2003), yakni dengan 
mengembangkan cara berpikir yang lebih adaptif (Nevid, dkk., 2005). Asumsi dasar Terapi Kognitif Perilaku (TKP) adalah adanya hubungan timbal balik antara proses berpikir (apa yang dipikirkan) dengan afeksi (pengalaman emosional), fisik dan perilaku (Roth, dkk. 2002; Stallard, 2005). TKP menekankan pentingnya perubahan kognitif dan perilaku untuk mengurangi simtom dan meningkatkan fungsi afek seseorang. TKP tidak hanya memperbaiki kognitif, namun juga mengubah perilaku, karena perubahan perilaku dąpat berpengaruh kuat pada pola pikir (Roth, dkk. 2002). Pemikiran tersebut misalnya karena khawatir, cemas, sedih, marah atau perasaan tidak nyaman (Stallard, 2006). Tujuan TKP adalah memperbaiki pikiran yang salah. Pikiran sering berubah dan hal tersebut akan berpengaruh pada suasana hati, fisik dan perilaku. Proses tersebut berpengaruh terhadap pembelajaran untuk mengevaluasi pemikiran serta mengubah seseorang menjadi rasional dan adaptif dengan cara mengubah pola pikir yang berpengaruh pada perasaan dan perilakunya (Roth, dkk. 2002). TKP menghubungkan antara apa yang dipikirkan, apa yang dirasakan, dan apa yang akan dilakukan. Hal tersebut dapat digambarkan pada diagram berikut ini (Stallard, 2005):

\section{Gambar 1. Diagram Kognitif Perilaku}

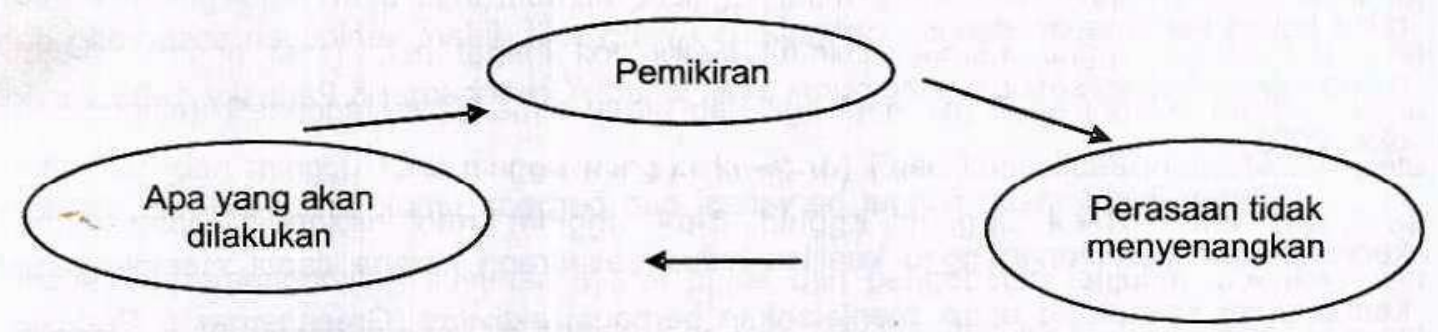

Keterangan: Pemikiran yang tidak menyenangkan akan mempengaruhi perasaan, sehingga menimbulkan perasaan yang tidak menyenangkan, kemudian akan berpengaruh pada perilakunya. Perilaku yang maladaptif juga akan berpengaruh pada pemikiran.

Terapi Kognitif Perilaku (TKP) efektif untuk mengurangi kecemasan dengan 4 kali pertemuan dan 6 materi. Adapun terapi kognitif perilaku menurut Stallard (2005) secara garis besar meliputi: psikoedukasi, sensitisasi emosi, relaksasi, desensitisasi sistematik (in vivo), bicara diri (selftalk), dan penguatan positif (positive reinforcement).

TKP meliputi psikoedukasi dengan pemberian informasi tentang prosedur medis, karena dengan pemberian informasi yang jelas dapat mengurangi kecemasan (Escudero, dkk., 2007; Weinman, 1981). Model kognitif memerlukan pengetahuan tentang kognitif dan emosi, agar seseorang mampu menjelaskan dan membedakan emosi dan pikiran yang 
sedang dirasakan, karena keduanya memiliki hukum sebab akibat (Reynolds, dkk. 2006; Runyon, \& Orvaschel. 1999). Penelitian Anderson (2004) mengatakan bahwa keterampilan relaksasi tidak hanya diberikan kepada anak, namun orangtua juga perlu diberikan informasi mengenai relaksasi. Bicara diri sering menghasilkan keyakinan, asumsi dan perubahan pemikiran. Anak dibantu mengidentifikasi kecemasannya dan menggantinya dengan bicara diri (Stallard, 2005). Pemberian penguatan merupakan pengembangan dari pendekatan perilaku, dimana target yang akan dicapai adalah mengatasi perilaku anak yang menjauhi stimulus terdahulu, dan terbukti efektif dengan menggunakan tropi/simbol (Anderson, 2004).

Bagan kerangka berpikirmengenai keterkaitan antara leukemia, kecemasan prosedur medis, dan Terapi Kognitif Perilaku dapat dilihat pada gambar 2:

Gambar 2 : Keterkaitan antara leukemia, kecemasan menghadapi prosedur medis dan Terapi Kognitif Perilaku.

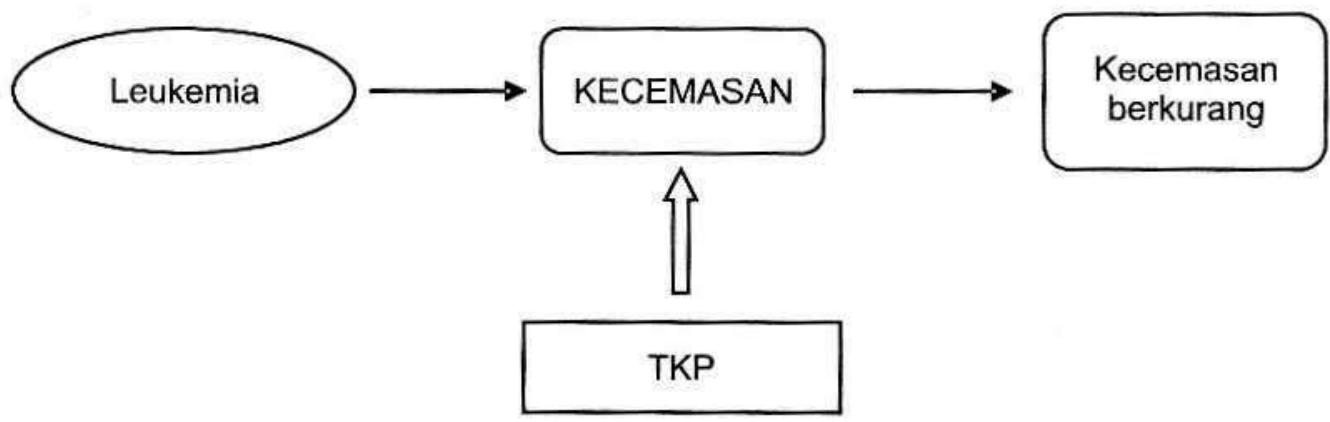

\section{Keterangan: $\longrightarrow$ : Menyebabkan : Mendapatkan}

Hipotesis yang diajukan dalam penelitian ini adalah Terapi Kognitif Perilaku efektif untuk mengurangi kecemasan menghadapi prosedur medis pada anak penderita leukemia.

\section{Subjek Penelitian}

\section{Metode Penelitian}

Subjek dalam penelitian ini berjumlah tiga orang anak yang menderita leukemia dengan kriteria usia tujuh hingga 11 tahun, sedang menjalani rawat inap maksimal enam sampai sepuluh minggu, dan mengalami kecemasan pada prosedur medis. Pasien diperoleh dari RSUP Dr. Sardjito yang direkomendasikan oleh dokter dan psikolog setempat.

\section{Rancangan Penelitian}

Penelitian ini menggunakan Desain dengan Subjek Tunggal (Single Subject Design) 
karena adanya keterbatasan jumlah subjek atau ukuran sampel kecil. Pengukuran pada penelitian ini dilakukan sebelum intervensi, selama intervensi dan setelah intervensi. Pengukuran sebelum intervensi dilakukan untuk mengukur tingkat kecemasan subjek sebelum diberikan intervensi (pertemuan pertama). Selama intervensi tingkat kecemasan subjek diukur dengan menggunakan pengukuran yang sama dengan alat ukur sebelum intervensi. Begitu pula di akhir pertemuan (pertemuan ke lima) tingkat kecemasan subjek diukur kembali (Shaughnessy, dkk., 2007).

\section{Pengumpulan Data}

Alat ukur. Alat ukur yang dipakai dalam penelitian ini antara lain: daftar pengecekan perilaku (behavioral checklist), skala kecemasan, buku harian, pedoman observasi dan pedoman wawancara.

1. Behavioral Checklist diadaptasi dari Positive Behaviors to Evaluated the Efficiency of the Treatment yang terdiri dari 13 item. Anak yang mampu mencapai tujuh atau lebih perilaku positif, maka anak telah mampu mengatasi kecemasannya, dan sebaliknya jika perilaku anak kurang dari tujuh item, maka anak mengalami kecemasan menghadapi prosedur medis.

2. Skala Kecemasan diadaptasi dari Pain Scale yang terdiri dari delapan macam nyeri. Pengukuran nyeri dilakukan untuk mengetahui tingkat kecemasan ketika menjalani tindakan medis, yaitu pengukuran suhu tubuh, pengambilan darah lewat jari, lewat siku sebelah dalam, pemasangan infus, injeksi/suntikan, LP, BMP. Skala tersebut dikemas dalam bahasa anak-anak dengan gambar yang menarik dan mudah dipahami. Validitas isi dilakukan dengan penilaian pakar (professional judgement).

3. Buku harian digunakan untuk memantau perasaan dan aktivitas yang dilakukan anak setiap hari, selama intervensi. Buku tersebut diisi oleh anak dan digunakan untuk evaluasi serta pemantauan kemajuan yang terjadi pada anak. Pedoman observasi digunakan untuk melihat perilaku anak yang muncul ketika menghadapi prosedur medis.

4. Pedoman wawancara dengan orangtua yang digunakan untuk menggali perilaku anak yang muncul ketika menghadapi prosedur medis.

Pelaksanaan pengukuran. Pengukuran kecemasan subjek menggunakan Skala Kecemasan dan diobservasi menggunakan Daftar Pengecekan Perilaku (Behavioral Checklist). Selama proses terapi sampai proses terapi berakhir subjek diberikan Skala Kecemasan dan Daftar Pengecekan Perilaku untuk memantau setiap perubahan subjek. 


\section{Intervensi}

Kecemasan yang dirasakan anak dapat menghambat prosedur medis dan jika prosedur medis terhambat, maka akan memperlambat proses kesembuhan. Intervensi pada penelitian ini menggunakan Terapi Kognitif Perilaku. Tujuan intervensi ini adalah untuk mengurangi kecemasan anak penderita leukemia terhadap prosedur medis.

Dalam penelitian ini diperlukan seorang terapis dan dibantu oleh observer. Modul panduan bagi terapis untuk melakukan intervensi disusun oleh peneliti. Panduan tersebut berisi materi Terapi Kognitif Perilaku secara spesifik dan sistematis mengenai langkahlangkah yang harus dilakukan terapis selama proses intervensi.

Ada beberapa tahap yang dilakukan dalam penelitian ini, yaitu:

Tahap awal. Tahap ini dilakukan sebelum memulai penelitian, di mana peneliti melakukan persiapan penelitian. Persiapan penelitian meliputi beberapa hal, yaitu: (1) proses pemilihan dan pembekalan terapis; (2) proses penyusunan alat ukur dan modul terapi kogitif perilaku (termasuk di dalamnya uji coba modul untuk memperbaiki instruksi dan bahasa yang digunakan dalam panduan Terapi Kognitif Perilaku pada subjek yang memiliki kriteria yang sama dengan subjek penelitian); (3) Seleksi subjek penelitian.

Pelaksanaan penelitian. Pelaksanaan penelitian berupa pemberian Terapi Kognitif Perilaku sebanyak 5 kali pertemuan, masing-masing selama 40-60 menit. Rincian pelaksanaan terapi dapat dilihat dalam Tabel 1. Jumlah pertemuan dalam terapi ini disesuaikan dengan tujuan yang akan dicapai. Adapun materi terapi kognitif perlakuan secara garis besar meliputi (Stallard, 2005) : psikoedukasi, sensitisasi emosi, relaksasi, bicara diri positif, penguatan positif, dan desensitisasi sistematik. 
Tabel 1. Jadwal Pelaksanaan Intervensi

\begin{tabular}{|c|c|c|c|}
\hline Perlakuan & Waktu & Tujuan & Cara \\
\hline $\begin{array}{l}\text { Pertemuan } 1 \\
\text { Menjalin hubungan } \\
\text { yang dekat } \\
\text { (building rapport) }\end{array}$ & 15 menit & $\begin{array}{l}\text { Memberi rasa aman, } \\
\text { Nyaman dan percaya } \\
\text { pada anak }\end{array}$ & Bermain \\
\hline Pre test & 10 menit & Mengukur rasa cemas & Skala dan obsevasi \\
\hline Sensitisasi emosi & 20 menit & Memonitor perasaan anak & $\begin{array}{l}\text { Berbagi cerita } \\
\text { (Shaning) }\end{array}$ \\
\hline $\begin{array}{l}\text { Pemberian tugas } \\
\text { menulis perasaan } \\
\text { pada buku harian }\end{array}$ & 15 menit & $\begin{array}{l}\text { Melatih anak untuk } \\
\text { mampu mengungkapkan } \\
\text { perasaannya }\end{array}$ & Buku harian \\
\hline $\begin{array}{l}\text { Pertemuan } 2 \\
\text { Evaluasi tugas } \\
\text { (buku harian) }\end{array}$ & 10 menit & Mengevaluasi kemajuan & Berbagi cerita \\
\hline $\begin{array}{l}\text { Psikoedukasi } \\
\text { tentang Leukemia }\end{array}$ & 50 menit & $\begin{array}{l}\text { Memberikan pengetahuan } \\
\text { dan pengertian tentang } \\
\text { sakit dan proses pengobatan } \\
\text { yang akan dijalani. }\end{array}$ & Cerita dan gambar \\
\hline $\begin{array}{l}\text { Pertemuan } 3 \\
\text { Evaluasi tugas } \\
\text { (buku harian) }\end{array}$ & 10 menit & Mengevaluasi kemajuan & Berbagi cerita \\
\hline Relaksasi & 20 menit & $\begin{array}{l}\text { Membantu anak untuk } \\
\text { lebih rileks ketika menghadapi } \\
\text { situasi yang tidak nyaman }\end{array}$ & Demonstrasi \\
\hline Desensitisasi & 30 menit & $\begin{array}{l}\text { Mengajarkan anak untuk } \\
\text { rileks selama proses medis, } \\
\text { dengan menghadirkan situasi } \\
\text { yang menekan. }\end{array}$ & $\begin{array}{l}\text { Demonstrasi dan } \\
\text { gambar }\end{array}$ \\
\hline $\begin{array}{l}\text { Pertemuan } 4 \\
\text { Evaluasi tugas } \\
\text { (buku harian) }\end{array}$ & 10 menit & Mengevaluasi kemajuan & Berbagi cerita \\
\hline Bicara diri & 30 menit & $\begin{array}{l}\text { Memotivasi anak dengan } \\
\text { menggunakan kata-kata positif. }\end{array}$ & Kartu ajaib \\
\hline Penguatan positif & 20 menit & $\begin{array}{l}\text { Mengubah perilaku anak dengan } \\
\text { memberi reward }\end{array}$ & Buku hadiah \\
\hline $\begin{array}{l}\text { Pertemuan } \mathbf{5} \\
\text { Evaluasi tugas } \\
\text { (buku harian) }\end{array}$ & 10 menit & Mengevaluasi kemajuan & Berbagi cerita \\
\hline Evaluasi keseluruhan & 20 menit & $\begin{array}{l}\text { Melihat perkembangan dan } \\
\text { kemajuan yang dialami }\end{array}$ & Berbagi cerita \\
\hline Pascates & 10 menit & Mengukur rasa cemas & Skala dan observasi \\
\hline
\end{tabular}

\section{Metode Analisis data}

Analisis terhadap data yang diperoleh dalam penelitian dilakukan dengan menggunakan metode kuantitatif dan kualitatif secara individual. 
Analisis secara kuantitatif. Analisis jenis ini dilakukan dengan menggunakan teknik visual inspection (Barlow \& Harsen, 1984). Langkahnya adalah dengan menampilkan grafik berdasarkan skor kecemasan yang diperoleh subjek sebelum, selama dan sesudah tritmen, sehingga diperoleh gambaran kecemasan masing-masing subjek.

Analisis secara kualitatif. Teknik ini digunakan untuk menarik kesimpulan dan dilakukan secara objektif dan sistematis dengan cara menganalisis data yang diperoleh sebelum, selama dan sesudah perlakuan. Data tersebut diperoleh dari Holsti (Moleong, 1998): (1) Buku harian, merupakan evaluasi terhadap kondisi subjek, baik pada perasaanperasaan dan pikiran subjek maupun segala aktivitas yang dilakukan subjek sehari-hari; (2) Wawancara dengan orang tua, dokter, perawat maupun subjek sendiri; dan (3) Observasi selama subjek menjalani prosedur medis.

\section{Hasil Penelitian}

Berdasarkan analisis data, didapatkan hasil untuk masing-masing subjek yang ditunjukkan dengan grafik Skala Kecemasan dan grafik Perilaku Positif.

Subjek PPD. Berdasarkan grafik skor kecemasan, tampak bahwa skor subjek mengalami penurunan pada pertemuan ke dua, ke tiga, ke lima. Pada Gambar 3 skor awal subjek menunjukkan angka 36 dan di akhir menunjukkan skor 21 . Gambar 4 menunjukkan bahwa subjek mengalami peningkatan pada perilaku positifnya, dari pertemuan pertama hingga terakhir skor awal 8 dan di akhir menunjukkan skor 13, meskipun pada pertemuan pertama dan ke empat menunjukkan skor yang sama dari pertemuan sebelumnya.

Gambar 3. Grafik skor kecemasan subjek PPD

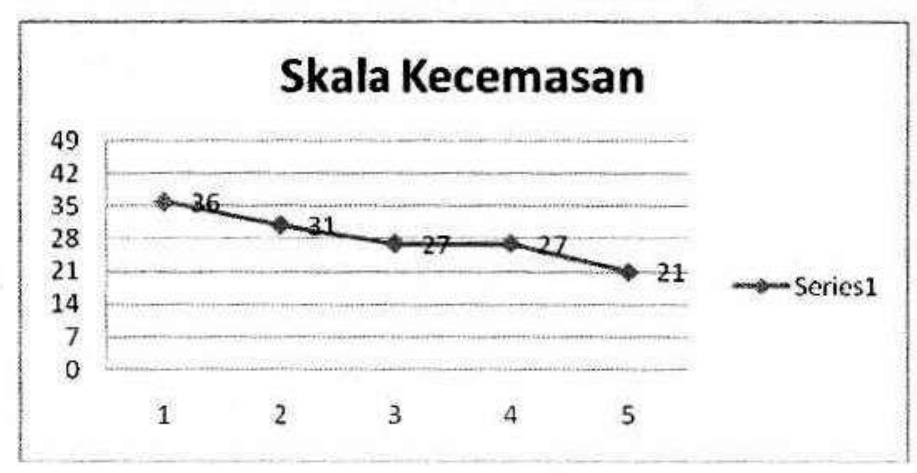


Gambar 4. Grafik perilaku positif subjek PPD

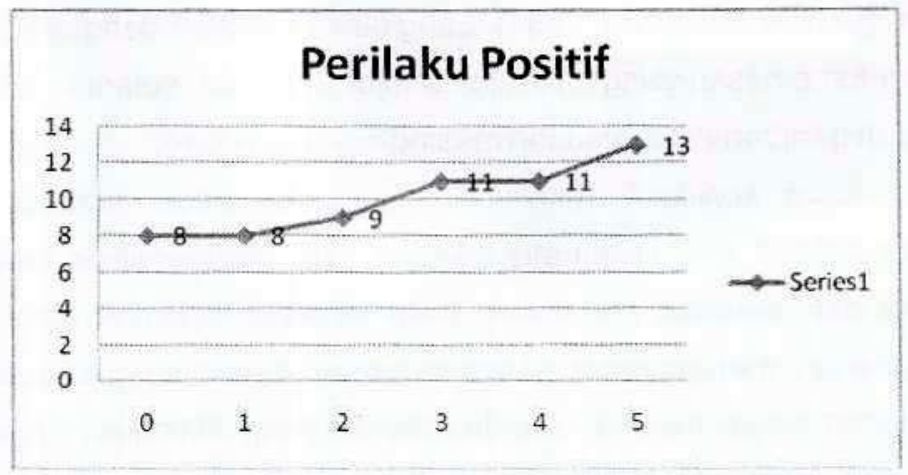

Sebelum intervensi, distorsi kognitif yang muncul pada subjek adalah bahwa subjek menganggap bahwa petugas medis (dokter maupun perawat) telah menyakitinya. Subjek juga merasa bahwa rumah sakit adalah tempat yang membosankan. Subjek menganggap bahwa segala aktivitas dan kegiatan sekolahnya menjadi terganggu. Hal tersebut memunculkan perilaku yang kurang kooperatif terhadap prosedur medis, subjek menjadi sering marah-marah terutama terhadap petugas medis, memberontak, bahkan menolak untuk diobati.

Setelah intervensi, subjek mampu mengalihkan perhatiannya ketika sedang menjalani prosedur medis, yakni dengan menggunakan teknik relaksasi ketika menghadapi prosedur medis. Subjek terlihat antusias mengikuti program ini. Hal tersebut subjek ungkapkan sendiri, karena menurutnya program seperti ini mampu menghilangkan kejenuhan dan memberi banyak pelajaran. Subjek mengaku baru pertama melakukan relaksasi dan mengisi buku harian, di mana hal tersebut menjadi pelajaran baru baginya.

Subjek DAS. Berdasarkan grafik skor kecemasan subjek, didapatkan bahwa subjek mengalami penurunan kecemasan. Meskipun pada pertemuan ke tiga subjek mengalami kenaikan skor kecemasan dari skor 25 naik menjadi 27. Namun, grafik menunjukkan adanya penurunan kecemasan hingga pertemuan terakhir. Hal terserbut dapat dilihat dari Gambar 5 , dari skor 28 turun hingga 20. 
Gambar 5. Grafik skor kecemasan subjek DAS

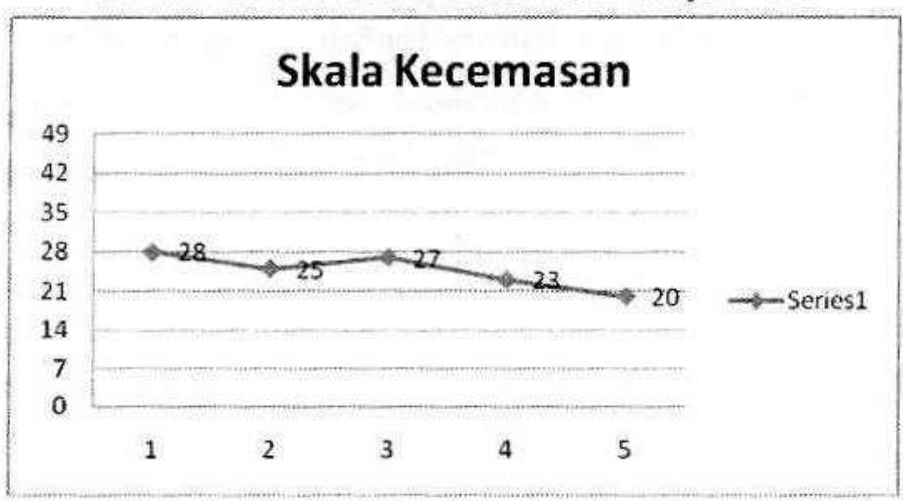

Gambar 6. Grafik perilaku positif subjek DAS

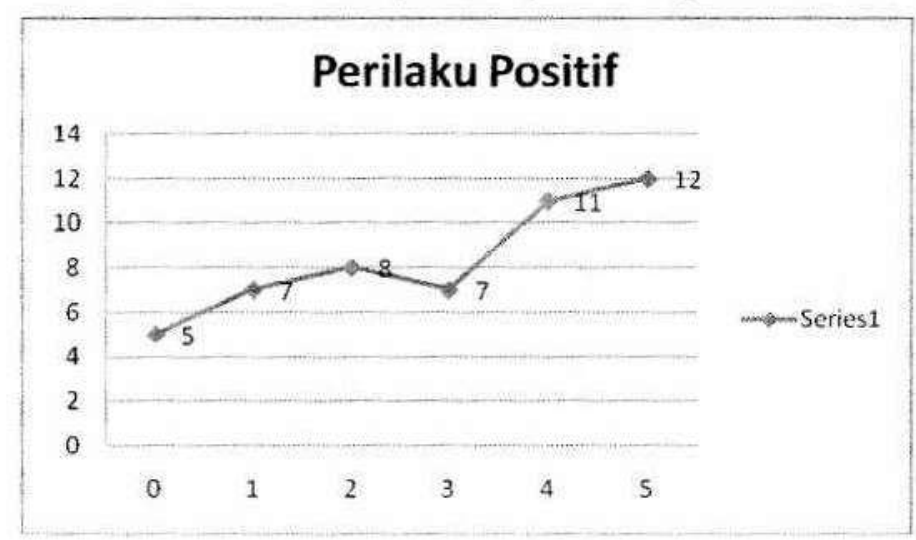

Grafik daftar pengecekan perilaku positif juga menunjukkan penurunan pada pertemuan ke tiga dari skor 8 menurun menjadi 7. Hal tersebut dapat dilihat pada Gambar 6 dan grafik menunjukkan peningkatan pada pertemuan-pertemuan setelahnya. Skor awal subjek adalah 5 perilaku positif, namun di akhir pertemuan subjek mampu memperoleh 12 perilaku positif.

Sebelum intervensi, distorsi kognitif yang muncul adalah bahwa subjek menganggap prosedur medis yang dijalani sangat menyakitkan dan tidak menyenangkan. Akibatnya, beberapa perilaku muncul saat menjalani prosedur medis seperti menangis, memberontak, histeris, menolak, melarikan diri.

Setelah intervensi, subjek merasa telah mendapat dampak positif dan merasa senang dengan program yang diperolehnya. Subjek merasa lebih bersemangat, tidak merasa jenuh, lebih banyak bercerita baik kepada terapis, perawat maupun ayahnya. Selain itu, subjek lebih kooperatif dalam menjalani prosedur medis. 
Subjek ER. Berdasarkan grafik skor kecemasan subjek, terlihat bahwa subjek mengalami penurunan tingkat kecemasan pada setiap pertemuannya. Begitu juga pada grafik perilaku positif subjek menunjukkan kenaikan, meskipun pada pertemuan ke dua tidak menunjukkan adanya perubahan skor. Gambar 7 menunjukkan skor awal 24 dan skor akhir 7.

Gambar 7. Grafik skor kecemasan subjek ER

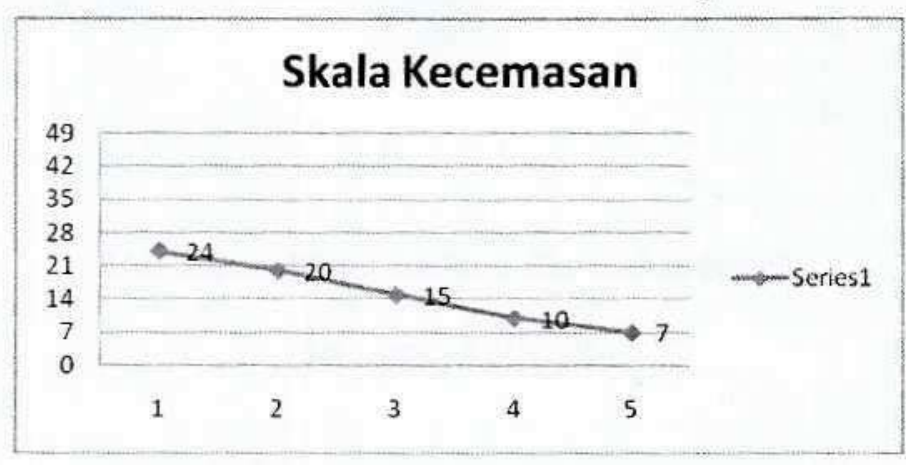

Gambar 8. Grafik perilaku positif subjek ER

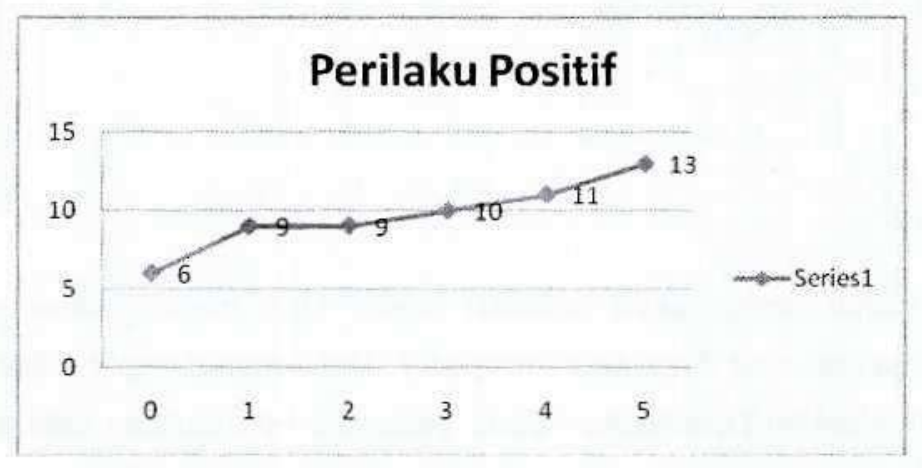

Sebelum intervensi, distorsi kognitif yang muncul adalah bahwa subjek menganggap prosedur medis adalah hal yang tidak menyenangkan. Subjek berpikir bahwa dirinya akan mengalami nasib yang sama dengan teman sekamarnya yang telah meninggal. Subjek juga berpikir bahwa aktivitas sekolahnya terganggu. Perilaku yang muncul pada subjek adalah subjek muntah jika meminum obat, merasa kehilangan nafsu makan, merasa sedih dan murung, menangis ketika menjalani prosedur medis.

Setelah intervensi, subjek merasa seperti mendapat semangat baru, bahkan subjek sering membuat sendiri kata-kata motivasi yang tidak berkaitan dengan prosedur medis, misalnya: "aku menang lomba". Hal tersebut menunjukkan bahwa terapi ini membuat subjek 
mendapatkan kembali semangatnya dan menunjukkan bahwa ada perubahan positif dalam dirinya.

\section{Pembahasan}

Berdasarkan serangkaian Terapi Kognitif Perilaku pada anak penderita leukemia, diperoleh hasil bahwa Terapi Kognitif Perilaku terbukti dapat menurunkan atau mengurangi kecemasan ketika menghadapi prosedur medis. Hal ini terlihat dari grafik penurunan skor kecemasan pada skala kecemasan dan adanya peningkatan pada perilaku positif dalam menghadapi prosedur medis, serta hasil kualitatif yang menjelaskan kondisi subjek. Penurunan skor kecemasan yang terlihat pada grafik hanya terjadi pada pertemuanpertemuan tertentu, dan tidak semua subjek menunjukkan penurunan kecemasan secara berkesinambungan. Beberapa subjek justru mengalami kenaikan skor kecemasan, dan subjek yang lain justru tidak mengalami perubahan skor. Begitu juga hasil yang terlihat dari perilaku positif yang menunjukkan kenaikan skor pada beberapa pertemuan. Tidak semua subjek mengalami peningkatan perilaku, bahkan mengalami penurunan. Secara kualitatif, subjekmenunjukkan perubahan lebih baik dari kondisi sebelumnya.

Kecemasan merupakan keadaan psikologis karena pengalaman yang tidak menyenangkan (Hersen, dkk., 1986). Sejak sakit dan dirawat di rumah sakit, subjek telah mendapatkan pengalaman yang tidak menyenangkan, yaitu merasa jenuh dan bosan dengan aktivitas di rumah sakit serta segala prosedur medis yang harus dijalani, merasa tersakiti, merasa terganggu aktivitasnya, dan merasa ada perubahan fisik. Perasaan-perasaan tersebut membuat subjek menjadi merasa cemas, tegang dan takut. Sesuatu yang negatif atau berpotensi memberikan akibat yang negatif dapat dipersepsikan sebagai sesuatu yang berbahaya, ancaman dan tantangan (Taylor, 2006). Prosedur medis yang harus dijalani oleh semua subjek dinilai sebagai suatu bahaya atau ancaman karena menimbulkan rasa sakit dan rasa tidak nyaman, sehingga memberikan dampak yang negatif yaitu meningkatnya kecemasan.

Terapi Kognitif Perilaku merupakan suatu bentuk psikoterapi yang mengintegrasikan teknik terapi kognitif dan perilaku yang berpusat pada kondisi di sini dan sekarang untuk membantu individu melakukan perubahan. Perubahan tidak hanya dalam perilaku nyata tetapi juga dalam pemikiran, keyakinan dan sikap yang mendasarinya (Nevid, dkk., 2005). Hasil penelitian menunjukkan bahwa Terapi Kognitif Perilaku dapat diberikan pada segala usia, dalam penelitian ini anak dengan disesuaikan kebutuhan masing-masing subjek. Roth, dkk. (2002) menyatakan bahwa Terapi Kognitif Perilaku dapat digunakan secara individual serta 
dapat digunakan untuk anak-anak, remaja dan dewasa dengan berbagai budaya dan latar belakang.

Teknik yang digunakan dalam Terapi Kognitif Perilaku telah disesuaikan dengan kondisi anak yang sakit dan lingkungan tempat tinggal anak, dalam hal ini adalah rumah sakit. Ruang bermain adalah tempat yang disukai oleh anak-anak, di mana anak merasa bebas, aman dan nyaman, sehingga anak mampu bermain sekaligus belajar ketika berada di ruang bermain. Situasi yang nyaman membuat anak mampu mengekspresikan perilaku maupun perasaannya. Anak menjadi lebih mudah diajak berbagi dan bercerita tentang apa yang dipikirkan dan apa yang dirasakan. Dalam sensitisasi emosi anak diajak untuk belajar mengungkapkan perasaannya, belajar bercerita hal-hal yang berkaitan dengan prosedur medis.

Psikoedukasi tentang penyakit dan apa yang harus dipersiapkan subjek adalah hal yang penting untuk subjek. Sebagai anak-anak, orangtua enggan memberitahu apa yang sedang dialaminya. Melalui tahap psikoedukasi anak akan diajak menelusuri penyakit, dampak, dan lama pengobatan agar anak memiliki pandangan yang berbeda mengenai kecemasan yang dirasakan. Penyampaian psikoedukasi dengan menggunakan buku cerita membantu anak dalam memahami informasi baru yang diterima (Stallard, 2005).

Teknik lain yang diajarkan kepada subjek adalah relaksasi. Relaksasi bertujuan untuk mengatasi gejala-gejala fisiologis yang timbul karena kecemasan. Subjek dilatih untuk melakukan relaksasi dalam menghadapi situasi-situasi yang menimbulkan kecemasan, sehingga subjek akan cenderung mengulangi latihan relaksasi karena merasakan efek nyaman yang ditimbulkan (Greenberger \& Padesky, 1995).

\section{Simpulan dan Rekomendasi}

Simpulan

Berdasarkan hasil penelitian dapat disimpulkan bahwa Terapi Kognitif Perilaku cenderung mampu mengurangi kecemasan ketika menghadapi prosedur medis pada anak penderita leukemia. Hasil observasi dan wawancara menunjukkan bahwa terdapat perubahan positif pada anak, yaitu anak menjadi lebih kooperatif dalam menjalani prosedur medis, mampu menjalin interaksi dengan petugas medis (dokter dan perawat), lebih bersemangat dan optimis, serta berkurangnya perilaku memberontak, menangis ataupun histeris sehingga anak mampu melewati fase-fase pengobatan. 


\section{Rekomendasi}

Beberapa hal yang perlu peneliti sarankan antara lain:

Rekomendasi bagi Orangtua. Orangtua merupakan orang terdekat anak. Orangtua dianggap mampu melindungi dan menjaga anak-anaknya, sehingga dalam proses medis yang berperan sangat penting adalah orangtua. Diharapkan orangtua mampu membantu anak selama mennjalani prosedur medis, dengan memberikan persiapan kepada anak berupa pengertian dan informasi tentang apa yang akan dihadapi anak selama berada di rumah sakit. Untuk itu, orangtua diharapkan mampu menjalin komunikasi dengan pihak rumah sakit terutama petugas medis dan psikolog setempat untuk mendapatkan informasi mengenai penyakit dan dampaknya bagi anak.

Rekomendasi bagi Petugas Medis. Petugas medis merupakan orang pertama yang berkaitan dengan prosedur medis, sehingga keberhasilan pengobatan juga tergantung kepada petugas medis yang meliputi dokter maupun perawat. Petugas medis hendaknya memberikan persiapan sedini mungkin kepada anak agar anak dapat menghadapi pengobatan selama di rumah sakit, mampu menjadi pribadi yang menyenangkan bagi anak, serta mampu memberikan informasi mengenai apa saja yang akan dilakukan selama pemeriksaan medis, sehingga anak tidak merasa disakiti.

Rekomendasi bagi Psikolog. Proses intervensi di rumah sakit tidak lepas dari peran penting psikolog. Adanya kerjasama dan komunikasi yang baik antara petugas medis dengan psikolog, akan mempermudah penanganan anak yang sakit, terutama dalam hal mempersiapkan anak menjalani prosedur medis. Intervensi tidak hanya dilakukan pada pasien, namun justru pada pihak keluarga sebagai orang terdekat pasien.

Rekomendasi Peneliti Selanjutnya. Untuk kesempurnaan terapi yang dilakukan, akan lebih baik jika karakteristik subjek sama, sehingga dapat dilakukan terapi secara kelompok. Terapi kognitif perilaku juga dapat dilakukan untuk menguji efektivitasnya pada penyakit kronis lainnya.

\section{Daftar Pustaka}

Anderson, K.G. 2004. Cognitive Behavior Therapy for Generalized Anxiety in a 6-Year-Old. Clinical Case Studies, 3, 216-233.

Barlow, D.H. \& Harsen, M. 1984. Singgle Case Experimental Designs $2^{\text {nd }}$. New York : Pengamon Press.

Escudero, R. M. P.; Kozasa, E. H.; Leite, J. R. 2007. Behavior Cognitive Protocol to Reduce Anxiety during a Magnetic Resonance Examination. International Journal of Magnetic Resonance Imaging, 01, 21-26. 
Gamayanti, I. L. 2006. Strres, Koping, Dan Pencapaian Adaptasi Anak yang Menderita Leukimia Limpoblastik Akut. Disertasi, tidak diterbitkan. Yogyakarta: Universitas Gadjah Mada.

Greenberger, D., \& Padesky, C.A. 1995. Mind Over Mood: Change How You Feel by Changing the Way You Think. New York: The Guiltford Press.

Hersen, M., Kazdin, A. E., \& Bellak, A. S. (Eds.). 1986. The Clinical Psychology Handbook. New York: Pergamon Press, Inc.

Manne, S. L., Andersen, B. L. 1991. Pain and Pain-Related Distress in Children With Cancer. Dalam J. P. Bush, \& S. W. Harkins (Eds.), Children in Pain: Clinical and Research Issue from a Developmental Perspective. New York: Springer-Verlag, Inc.

Nelson, W. E., Vaughan, V. C., \& McKay, R. J. 1969. Textbook of Pediatrics, 9th Ed. Philadelphia: Saunders.

Moleong, I.J. 1998. Metodologi Penelitian Kualitatif. Bandung: Remaja Rosdakarya.

Nevid, J. S., Rathus, S. A., \& Greene, B. 2005. Psikologi Abnormal. Terjemahan. Jakarta: Penerbit Erlangga.

Reynolds, S., Girling, E., Coker, S., \& Eastwood, L. 2006. The Effect of Mental Health Problems on Children's Ability to Discriminate Amongst Thought, Feelings and Behaviours. Cognitive Therapy Research, 30, 599-607.

Roth, D. A., Eng, W., \& Heimberg, R.G. 2002. Cognitive Behavior Therapy. Encyclopedia of Psychotherapy, 1,451-458.

Runyon, M. K., \& Orvaschel, H. 1999. Cognitive-Behavioral Treatment for Adolescent Depression Complicated by Childhood Trauma: A Case Illustration. Journal of Clinical Child Psychology and Psychiatry, 4, 493-504.

Shaughnessy, J. J., Zechmeister, E. B., \& Zechmeister, J. S. 2007. Metodologi Penelitian Psikologi. Terjemahan. Yogyakarta: Pustaka pelajar.

Sheridan, C. L., \& Radmacher, S. A. 1992. Health Psychology, Challenging The Biomedical Model. New York: John Wiley \& Sons, Inc.

Siegel, L. J., \& Hudson, B. O. 1992. Hospitalization and Medical Care of Children. Dalam C. E. Walker, M. C. Roberts (Eds), Handbook of Clinical Child Psychology, 2nd Edition. New York: John Wiley \& Sons, Inc.

Stallard, P. 2005. Children's Guide to Think Good-Feel Good. London: British Library of Cataloguing Publication Data.

Taylor, S. E. 2006. Health Psychology. New York: The McGraw-Hill Companies, Inc..

Weinman, J. 1981. An Outline of Psychology as Applied to Medicine. London: John Wright and Sons, Ltd. 
Westra, H. A., \& Pheonix, E. 2003. Motivational Enhancement Therapy in Two Cases of Anxiety Disorder. Clinical Case Studies, 2, 306-322.

Zempsky, W. T., Cravero, J. P. 2004. The Committee on Pediatric Emergency Medicine and Section on Anesthesiology and Pain Medicine. Relief of Pain and Anxiety of Pediatric Patiens in Emergency Medical Systems. Journal of Pediatric, 114, 1348-1356.

Ziegler, D. S., Pozza, L.D., Waters, K. D., \& Marshall, G. M. 2005. Advances in Childhood Leukaemea: Successful Clinical-Trials Research Leads to Individualized Therapy. MJA, 182, 78-81. 
